\title{
EXÚ'S WORK - THE AGENCY OF RITUAL OBJECTS IN SOUTHEAST BRAZILIAN UMBANDA
}

\author{
ELEONORA A. LUNDELL \\ M.A., PhD Student \\ Department of World Cultures \\ University of Helsinki \\ PL 00014 Helsingin yliopisto \\ Unioninkatu 38 A, Helsinki, Finland \\ e-mail: eleonora.lundell@helsinki.fi
}

\begin{abstract}
This article concentrates on the material side of religious intimacy in Afro-Brazilian Umbanda through an 'ontographic' perspective as well as looking at materiality as evidence. It is based on an eleven-month fieldwork period among devotees, clients and individual practitioners of Umbanda in Southeast Brazilian metropolises, especially in São Paulo. In people's experiences of spiritual work (trabalho) and spiritual development (desenvolvimento) carried out with Exús - guardians, guides and protectors who have, after their death, returned in order to work for people's wellbeing - ritual objects (such as bodies, clothes, beverages, herbs, cigarettes, candles, songs) are seen as constitutive in knowledge production and life transformation. The central claim in this article is that diverse material and immaterial objects through which Exús interact and materialise, are neither primarily symbolic nor representative, but are re-configurative.
\end{abstract}

KEYWORDS: Umbanda • Exú • ritual objects • materiality • Afro-Brazilian religion - São Paulo

\section{N T RODUCTION}

Pomba Giras (female Exú) are beautiful women, who like to dress up, talk, laugh, drink and smoke cigarettes [...] there are so many people who want to talk with them. Usually it's about love, work, daily issues [...] they become happy with the hope that Exús show to them through baths and offerings, and little by little, they find themselves. (Pai Marcelo, ${ }^{2}$ in São Paulo, 2011)

In this article I address the materiality of ritual communication between people and Exús - guardians, guides and protectors who according to the practitioners of Umbanda,

* I gratefully acknowledge the help of my PhD supervisor Pirjo Kristiina Virtanen, as well as the University of Helsinki Research Funds, without which the present paper could have not been completed. I also express my deepest gratitude to all of the people in Brazil who have helped me during my research process. 


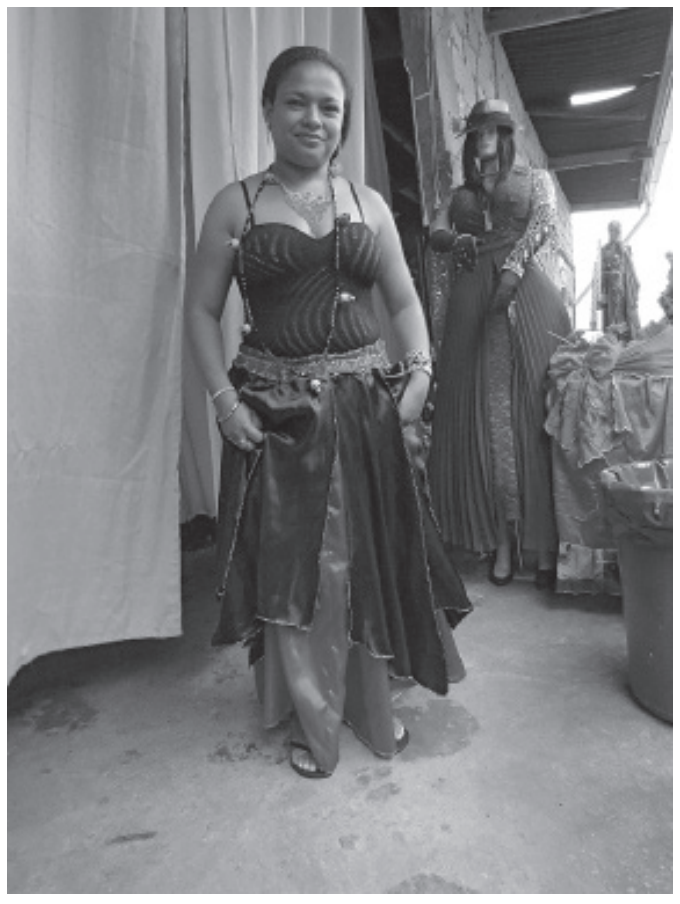

Photo 1. Umbanda medium with Pomba Gira's (female Exú spirit entity) ${ }^{1}$ dress and guia necklace. Photo by Eleonora Lundell. once had their human life and now have returned in order to work for people's wellbeing. During my fieldwork, which I carried out mainly in São Paulo, I learned that today in Southeast Brazilian Umbanda houses, the most crowded ritual gatherings (gira) ${ }^{3}$ are those in which different Exús are interacted with, due to complicated situations surrounding health, wealth or love. These are called rituals of the left side (esquerda), in which male Exús, female (Pomba Giras), and child Exús (Exú Mirims) act, as well as some other 'spirit entities of the right side', known as está mais pra esquerda, i.e. capable of working in the left. ${ }^{4}$ For Umbanda practitioners (umbandista) ${ }^{5}$ the Exús are of all races, ethnic origins, social backgrounds and nationalities that have existed in Brazil throughout its history. They are known especially as people who lived on the margins of society as petty criminals, gamblers, prostitutes, and homeless children (see Prandi 2005: 81-82; Hayes 2011: 3-4), but also according to many Umbanda practitioners, as respected lawyers, politicians and doctors. Despite different social backgrounds, the common factor is that at some point during their lives, they became familiar with marginality, crime, inequality, misfortune, or betrayal. This is why they have the special ability of being able to take care of the extremely difficult problems that Brazilians face during their lifetimes.

Exú spirit entities are incorporated into human bodies to do their work. The incorporation is enabled through a process called spiritual development (desenvolvimento), which happens through the materialisation and material mediations of the Exús' vibration in humans, and in material and immaterial objects. Through materialisation, Exús become members of the social networks formed by their human and non-human actors. While performing their spiritual work (trabalho), Exús use a wide range of ritual paraphernalia: cachaça (a distilled spirit made from sugar cane), chicken blood, capes, hats, dresses, candles, leaves, gunpowder, roses, cigarettes, etc.

In order to understand the significance of materiality in the experience of Umbanda practitioners, this article looks at the ontological modalities of materiality from an ontographic perspective. In other words, the aim is "to chart out the ontological presuppositions required to make sense of a given body of ethnographic material" (Holbraad 2011: 82). This kind of theoretical approach is based on the acknowledgement of epistemological problems faced by ethnographers working in realities/worlds in which the notion of materiality radically differs from modern Western mainstream ideas. In Thinking through Things, Amiria Henare, Martin Holbraad and Sari Wastell (2007) asked if 
things could speak for themselves, and what their voices would sound like. According to Holbraad (2011), this "pragmatological engagement with the voices of things" enables things to speak through the ethnographic association with Native voices, which is in fact a continuum for the wider anthropological concern about the emancipation of 'the other'. However, the "things manifesto", as Hoolbraad puts it, goes beyond subaltern radicalism (where the preoccupation is with the voices of subaltern peoples (Spivak 1988), challenging the epistemological ground through which Native voices are analysed (Holbraad 2011: 3). More closely related to my ethnographic fields, anthropologist Marcio Goldman (2011), who has carried out an extended study of the Brazilian Candomblé, showed how - because of the absence of Native voices in earlier studies fetishism, a widely used concept to describe the position of materiality in Candomblé rituals, has repeatedly failed to explain the ontologically essential ritual dimensions, such as agency and creation. Goldman has called for an "anthropological symmetrisation" suggesting that, "we should perhaps learn from them [informants] other ways to think about this process of creation and agency in general and gain access to other ontological modalities". According to Goldman, informants should not even be called such, but should be seen as "actors, endowed with their own reflexivity, as theoreticians with whom we should talk and from whom we can learn" (Goldman 2011: 121).

On the other hand, Webb Keane (2009: 124) has also stated, concerning the problematics of evidence related to religions, that "one basis for anthropological comparison, then, might be to start by attending to the implications of the materiality of practices and objects, rather than those immaterial things we might take them as evidence for". Thus,

religions may not always demand beliefs, but they will always involve material forms. It is in that materiality that they are part of experience and provoke responses, that they have public lives and enter into ongoing chains of causes and consequences. (Ibid.)

Following these ideas, my study relies on the experiential level of Umbanda practitioners, studied through the different verbal, behavioural and material articulations of ritual communication with Exús. By using this approach my aim is to reach out for a wider perspective on materiality in ritual communication. Thus, earlier studies on materiality in religions (i.e. so-called fetishism) have largely been based on an anthropocentric view in which dichotomies such as human-spirit, nature-culture, subject-objects, have been central in understanding materiality as symbolic or representative signs of the 'facts' behind it - cultural, psychological, biological or political. The previous discussion on materiality based on ethnographic knowledge has, however, shown otherwise. Especially the works of Holbraad (2012a) on Cuban Ifá divination, Goldman (2011) and Roger Sansi (2013) on Candomblé and Halloy (2013) on Xangô rituals, have provided an understanding of Afro-Brazilian and Afro-Cuban religious worlds in which the notion of materiality epistemologically escapes the concepts of earlier analyses, challenging them, but also offering fruitful grounds for expanding the analysis. Similarly, I will try to delve deeper into the infrequently studied world of Umbanda, and more precisely, into the realm of religiosity lived in Southeast Brazilian Umbanda houses, where the religion's significance is primarily about spiritual work (trabalho), rather than institutionalised hierarchies and religious dogma. Through this observation my aim is to push 
the earlier studies' interpretations of Umbanda as syncretic/hybrid/'a less African'6 religion towards an analysis of the materiality of religious/spiritual practices and their relatedness to knowledge production and agency.

The article is based on data collected during an eleven-month fieldwork period in São Paulo and Rio de Janeiro between 2011 and 2015, where I have learned from and worked with leaders, affiliates, and clients of Umbanda houses, as well as with their family members and friends and the spirit entities of Umbanda. I have visited diverse religious locations, including worship houses, homes and shops selling religious artefacts.

In this article I look at materiality in ritual communication within the two abovementioned contextually significant events: spiritual work and spiritual development. I will demonstrate that materialisation and material mediation in Umbandista worlds related to Exús are based on a particular spiritual-material dualism. This dualism does not, however, correspond with the commonly acknowledged epistemological dichotomies in theories of religion, such as matter-spirit, subject-object, etc., but in fact challenges the capability of these Western dichotomies to serve as ways of understanding religious experience in the Southeast Brazilian context.

In the first section I shall introduce Umbanda in the contemporary Southeast Brazilian context. Furthermore, within the following two sections I will introduce the experiential level of people I have worked with, striving to enlighten the agency, multiplicity and constitution of the body-object ${ }^{7}$ as well as other (non-human) ritual objects - which seem to be the two fundamental elements in the ritual practice. Later, I will return to the human-Exú relationship by pointing out some ideas about how ontologically perceived materiality is related to companionship, which in fact is the primary emphasis people give for their relationship with the Exús. I will suggest that the relation (in its material and immaterial forms) between people and Exús could perhaps be more broadly understood when looking at it from an 'inter-species', rather, than from a 'transcendence' perspective. Thus, I see that if we take the Umbanda practitioners' ontological presuppositions seriously when treating the emerging material-semiotic forms of human-Exú relations, we could benefit from Donna Haraway's ideas about significant otherness as a process in which both ontological beings in question (human and Exú) become and enact each other. This process, what Haraway (2003: 24) calls "the art of naturecultures" (while describing the interspecies relations and companionship between people and dogs), relies on the understanding of relation, as the smallest unit of analysis, through which the material-semiotic forms of each companion takes place. $€$

\section{THE SOCIO-POLITICS OF UMBANDA IN SOUTHEAST BRAZIL}

Based on socio-historical contextualisation, the very few studies that have focused on Umbanda have described it as a truly Brazilian, syncretistic and hybrid religion par excellence (Brown 1986; Negrão 1993; Jensen 1998; Ferreira da Silva 2005; Prandi 2005; Engler 2012;). ${ }^{8}$ According to the official myth of Umbanda, in the 1920s Zélio de Morães incorporated an indigenous spirit entity Caboclo Sete Encruzilhadas in the sub-urban area of Rio de Janeiro. This reincarnated indigenous Caboclo declared himself to be the founder of a new religion called Umbanda. Historically, Umbanda's myth of origin is 
related to a time when Brazil was enthusiastically searching for its national identity, emphasising the multiracial origin of its population. Umbanda was at that time celebrated as the truly Brazilian religion as it cultivated equally Catholic saints, African Orixás, ${ }^{9}$ Brazilian indigenous ancestors and had strongly adapted Kardec's spiritualism (Espiritismo Kardecista) ${ }^{10}$ in its ways of knowing and enacting the spiritual world (ibid.). Within the Umbanda carta magna signed by the largest Umbanda federations and several locally acknowledged Umbanda leaders on October 13, 2015 in São Paulo, Umbanda is described as a monotheistic religion, with an "afro-indigenous-euro-Brazilian" doctrine. The carta magna declares that in Umbanda the African Orixás are syncretised with Catholic saints and cultivated as spiritual guides and mentors, "God's ministers", who assist God's work. It also points out that Umbanda practitioners believes in reincarnation and the incorporation i.e. the bodily manifestations/materialization of the spirits of the dead, and that these spirit entities help people in their refinement as humans and conduct them towards God. Moreover, Umbanda considers, according to carta magna, all nature to be "God's altar", where people can have conversations with the creator.

Even though several Umbanda authorities have come to an agreement concerning carta magna, in practice it is commonly acknowledged that more than one Umbanda exists. For instance, White Umbanda (Umbanda Branca) and Esoteric Umbanda (Umbanda Esotérica) are more closely related to Kardec's Spiritism (of European origin), and do not accept the more African influences within their ritual practice. However, the Umbandas I have investigated during my field research in the state of São Paulo have been more identifiable with what has been locally called the African Umbanda (Umbanda Africani$z a d a)$, referring to the strong influence of African-rooted religions, such as Candomblé. Lindsay Hale (2009: xv) in her comprehensive study of Umbanda in Rio de Janeiro uses the terms Afro-Brazilian and White Umbandas when talking about this division. In São Paulo the four more or less Afro-Brazilian Umbandas I have come to know during my fieldwork use atabaque drums and organise public cultivation of Exús, and two of them perform animal offerings, which are mainly absent within the public ceremonies in the white versions of Umbanda. However, similar to what Kelly Hayes (2011) discusses in her extensive work on Pomba Gira figures in Rio de Janeiro, I have observed, that the usage of concepts such as Candomblé, Umbanda, Macumba ${ }^{11}$ and Espiritismo are not unified, and often Macumba and Espiritismo, for instance, are used as generic terms in reference to all Afro-Brazilian religions (Hayes 2011: 19).

Despite the differences in attitudes towards certain elements, the principal function of all Umbandas is to perform spiritual work for those who are in need. Umbanda has its devotees and clients, of which the latter group consists of a clearly larger number of people. The number of Umbanda devotees in Brazil (around 400,000), according to the Brazilian national census (IBGE 2010), is marginal considering the size of the whole Brazilian population. However, this does not indicate the number of people with different religious backgrounds who visit Umbanda worship houses temporarily in search of spiritual advice and healing and as an aid in emergencies. Thus the cultural significance of Umbanda cannot be measured through these statistics (see also Teixeira 2013). However, it is worth noting that in 2010 nearly 25 per cent of all declared Umbandistas (according to the census) lived in São Paulo state, where during the past decade Umbanda had slightly increased its popularity. The other strong areas of Umbanda 
devotion are the states of Rio de Janeiro and Rio Grande do Sul, indicating popularity especially in the southern and southeastern areas, which are among the wealthiest in Brazil (IBGE 2010). Umbanda, in fact, is known in all parts of Brazil, although the practice, as well as the diversity of spirit entities performing spiritual work, varies greatly in different parts of the country. Generally Umbanda is practised in specific casas (houses), terreiros (worship houses), ${ }^{12}$ centros (centres) and tendas (tents), as well as in private homes, cemeteries, crossroads, waterfalls and forests. The terreiro communities and rituals are led by leaders (mãe-de-santo/pai-de-santo) as well as by the spirit entities the leaders 'carry'.

In São Paulo, there is a growing number of Umbanda activists who are very strict in demanding Umbanda's rights as a real religion, as well as drawing a clear dogmatic line between Umbanda, Candomblé and Kardec's spiritualism. These attitudes mirror the inferior position Umbanda has had over the past decades in comparison with other religions (see Engler 2012). One outcome of the theologisation and politicisation processes has been for instance, the above-mentioned carta magna, but also the inauguration of the first faculty of Umbanda theology, approved by the Ministry of Education in the city of São Paulo in 2003. Today, despite the recently increased religious intolerance towards Afro-Brazilian and Spiritist devotion, in the state of São Paulo there are public places for Umbanda practice, such as Ilê, a special ritual place inside a Catholic cemetery, as well as an Umbanda sanctuary (Santuario de Umbanda) where practitioners can temporarily use the space for rituals that require the immediate presence of nature elements (forests and waterfalls), or a safe place for Exús works and the dispatch (despacho) of broken ritual objects. Active devotees working in Umbanda federations have also organised large events in public places for commonly cultivated Orixás (such as Ogum and Iemanjá), which gather hundreds of people from many Afro-Brazilian religions in the area. In the Greater São Paulo, some Afro-Brazilian religious leaders and some politicians from the Labour Party (Partido dos Trabalhadores), have been active and gained visibility in the media and in politics over the last few years in their attempts to diminish discrimination by the more fanatical Pentecostals. Thus, during past decades there have been numerous police investigations and court hearings on cases of religious intolerance (intolerância religiosa), varying from verbal insults to physical violence (see for example da Silva 2007).

The Umbanda houses I have come to know in São Paulo are situated in socio-economically different areas, from upper middle class areas to poor sub-urban contexts. Here the ethnographic examples are drawn mainly from one Umbanda house led by Pai Marcelo in the city of Diadema. ${ }^{13}$ Among my interlocutors many Umbandistas, as well as religious clientele have been raised as Catholics. They often describe childhood memories of Kardec's spiritualist centres where their mediunity was first discovered; later on they might have passed through Pentecostal churches and found their way to Umbanda, or have carried out an initiation ritual for instance in Candomblé, in which they might have established deeper relations with their Orixás. Yet, people in these Umbandas commonly define themselves as Catholic, Umbandista or Espírita (in reference to Kardec's spiritualism, but also to Afro-Brazilian religiosity in general). This by no means signifies that the work in Catholicism, Umbanda, Candomblé or Kardec's spiritualism is considered the same. On the contrary, the works carried out for instance in Candomblé and Umbanda are considered very different, including energies, founda- 
tions, non-human entities, practices, and so on. Thus, in all these different places the ontologically central balance between spiritual (lado espiritual) and material (lado material) sides (recognised by most Brazilians) is worked from different angles, that can, however, serve people in different stages of life and spiritual development. In other words, it seems that different religious worlds co-exist and merge within the lives of my interlocutors. Thus, a fruitful approach would be to analyse the ontological formation of personhood (which I do in the following section). Indeed, the urban multi-ethnic cosmopolitan context, especially in São Paulo, also flavours the close intimacy of different religious/spiritual influences that people come across in their everyday lives.

Moreover, the socio-cultural inferiority of Umbanda still affects how people identify themselves in the religious field. Despite the hopes of Umbanda activists to unify and politicise Umbanda, it is still very common that 'religion' in Southeast Brazil is associated with Catholic and Pentecostal Churches. Thus, Umbanda as a 'religion' is marginal, but Afro-Brazilian forms of spirituality are nevertheless culturally very influential forms of engendered sociality and are also practised by many non-Umbandistas. Thus, what in my view is essential in terms of understanding religion and the position of Afro-Brazilian religions in a wider sense, requires attention to be paid to the services offered by different religious actors, and more precisely as stated above, to the notion of 'person' as well as to the logic and technology of 'spiritual work' (trabalho espiritual) in different ritual contexts.

\section{LUCIANE'S HEALING IN EXÚ RITUAL GATHERING}

That Saturday, you saw me, I was very ill. I was in the hospital and the doctors said they would have to operate on my spine. Before that, I had consulted a spirit entity here in this house, Seu Zé Pelintra, and he had said that I didn't have to have an operation even if the doctors wanted it, I wouldn't have to agree. He said he would put me back on my feet, and really, I am feeling better every day. Yesterday I had to use a walking stick and today I am walking on my own. Today I took off the orthopedic corset and I am recuperating every day [...]. This Saturday we did one spiritual job [trabalho]. During that moment I felt I was healed, and every day I am getting better and recuperating. Like this was my real surgery [...]. We gave an offering [oferenda] to Pomba Gira [female Exú spirit entity] and Exú. Manioc flour [farofa] for the woman [Pomba Gira], with honey, we gave blood... we killed an animal, a hen, and gave champagne and cigarettes. And for Exú, manioc flour, palm oil [dendê], a hen, cachaça, tobacco, and then we did the cleaning with hominy [canjica], popcorn, mamona leaves, and afterwards we exploded gunpowder, that is the element of purification which liberates the energies. There was Mãe Rosana's Seu Zé Pilintra, Pai Marcelo's Seu Ventania, and the cambônes who always help in the process [...]. I really felt, and I say truly that I felt like that was my surgery, like I was healed at that moment, like I was liberated from all of the bad that was in my body and in my spirit, the bad that was prejudicing me. (Luciane, in Diadema 2011)

I happened to be around during Luciane's healing session in a closed Umbanda gira (ritual gathering). The Umbanda house where the healing took place was located in a 


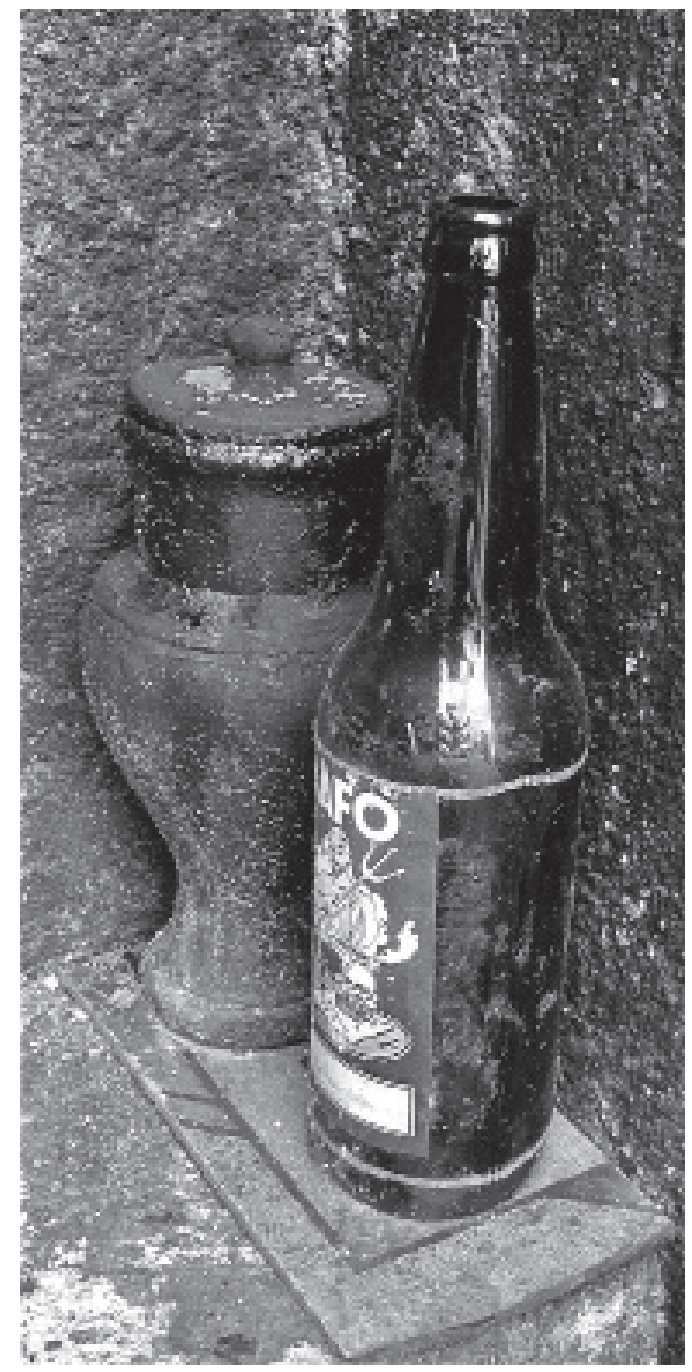

Photo 2. Firmeza de Exú in Pai Marcelo's Umbanda house. Photo by Alexandre Riviello. lower-middle class resident area and led by Pai Marcelo, a well-known Umbanda leader in Diadema and owner of several religious artefact shops in the area. The house was known by its dedication to Exú spirit entities, who were called to work there three times a month. Once a month the ritual gathering was closed (gira fechada), only developing mediums could participate in order to become more familiar with their spirit entities and those of other developing mediums.

The approximately fifty-squaremetre Umbanda house, painted in black ink both inside and out, was lit only by red and black candles that night. Descending the narrow staircase from the front gate, no one is able to enter without passing the spiritual alarm system, called firmeza de Exú, a ritually prepared clay pot consisting of secret elements of Exú as well as bottled cachaça by its side as an offering.

Before reaching the worship house, the energy of Exú was there again, below the earth, in a hole, where the offerings are buried and the used objects are thrown in Marcelo's house. Luciane's healing took place there that night.

Getting almost to the door of the Umbanda house, there is Exú again in his own house (casa de Exú). Exú Ventania's statue is an offering and has secret ingredients that are contained in the statue, making it a materialized Exú.

Inside the Umbanda house the many Exús were present as clay statues. Pai Marcelo explained that all of the mediums had their own Exú statues situated in the cafúa, a separate corner inside the Umbanda house. The statues were located in the floor close to the three walls that separated cafúa from the rest of the worship space. A black wooden throne was located in the middle of cafúa for Exú Ventania. The Exús located in cafúatogether with the spirit entities and Orixás that are located in separated congá (altar) and worked in the right-sided rituals - form the spiritual fluid (corrente espiritual) of the Umbanda house.

I was not expecting to witness Luciane's healing ritual that night, in fact that was the first time I met her. Some days later when I returned to conduct interviews with her and some other affiliated members of Pai Marcelo's Umbanda house, I had a chance to 


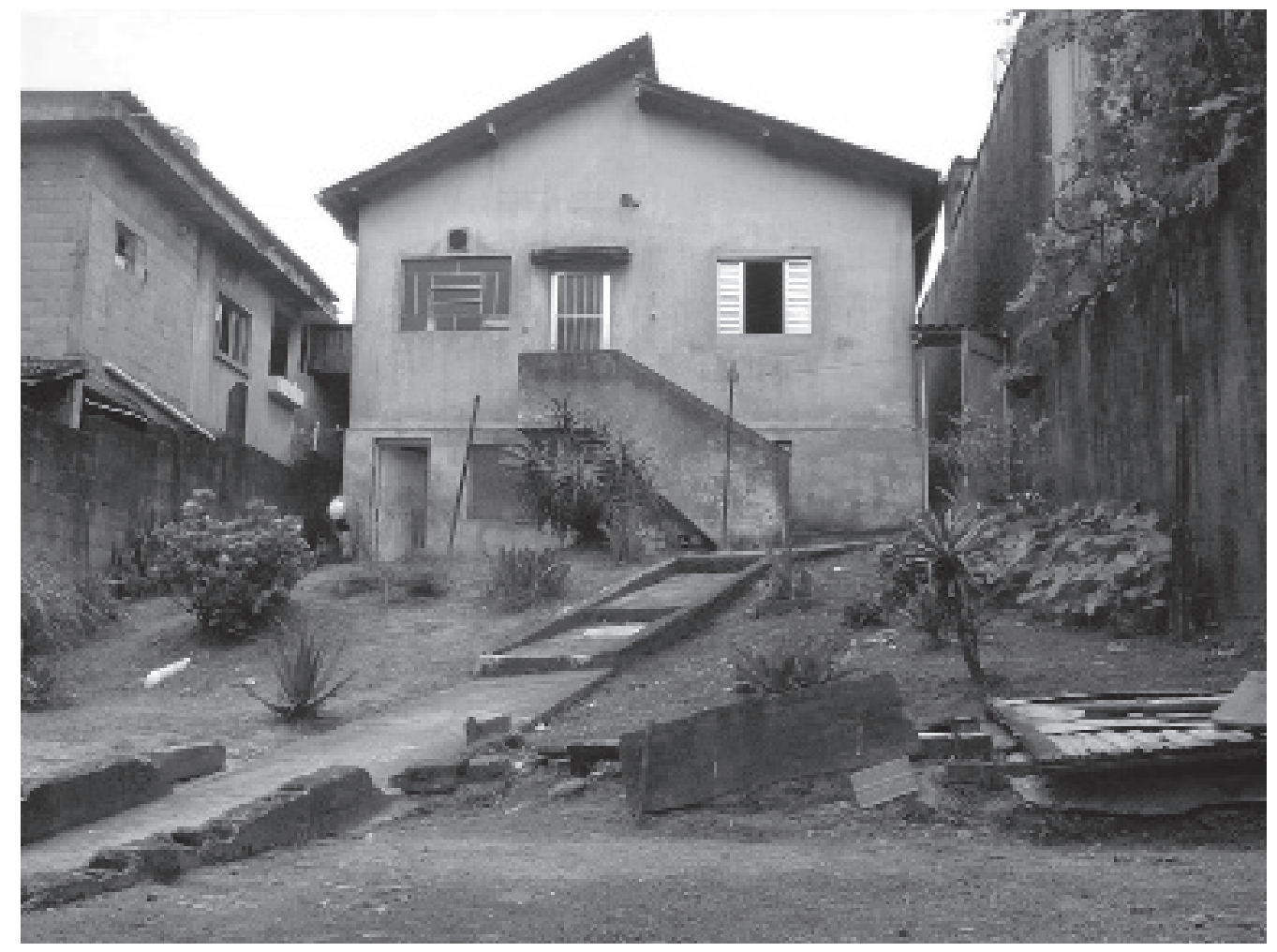

Photo 3. The front yard of Pai Marcelo's Umbanda house. The hole used in Exús work is hidden under a wooden cover on the ground. Photo by Alexandre Riviello.

talk about the healing event with Luciane more specifically. ${ }^{14}$ I found out that a then 35-year-old white architect from São Paulo, Luciane, had recently moved to Diadema in order to be closer to the Umbanda house and her new friends from the worship house community. Her spiritual career had started with Orthodox Catholicism, into which she was baptised, as her parents were originally from Greece. Together with her father she had studied Kardec's spiritualism at an early age and later on was initiated into Candomblé as Orixá Iansã's daughter. It had been clear to Luci-

Photo 4. The sidewall of Casa de Exú with Exú Ventania's ponto riscado. Photo by Alexandre Riviello.

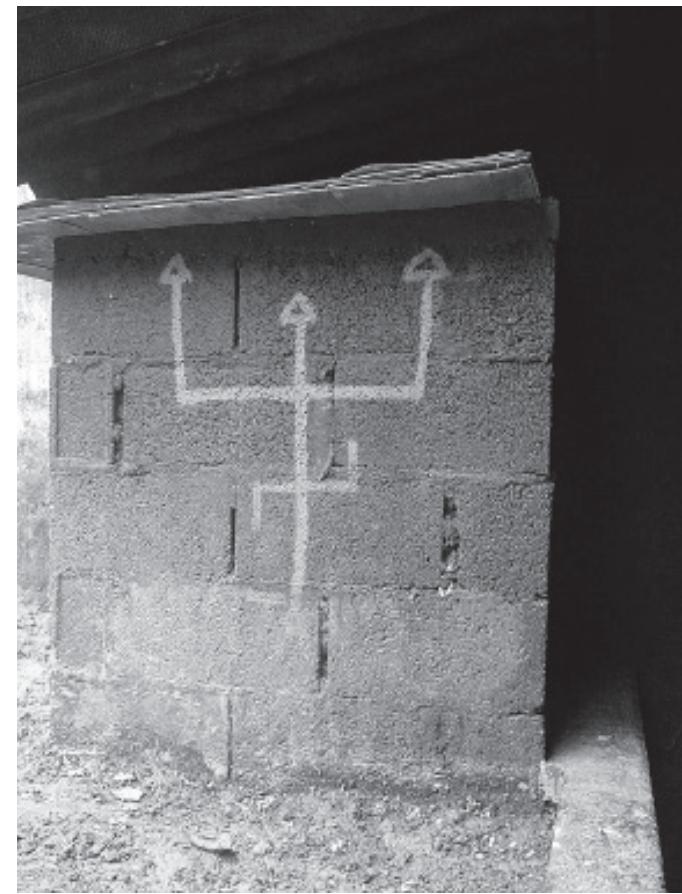




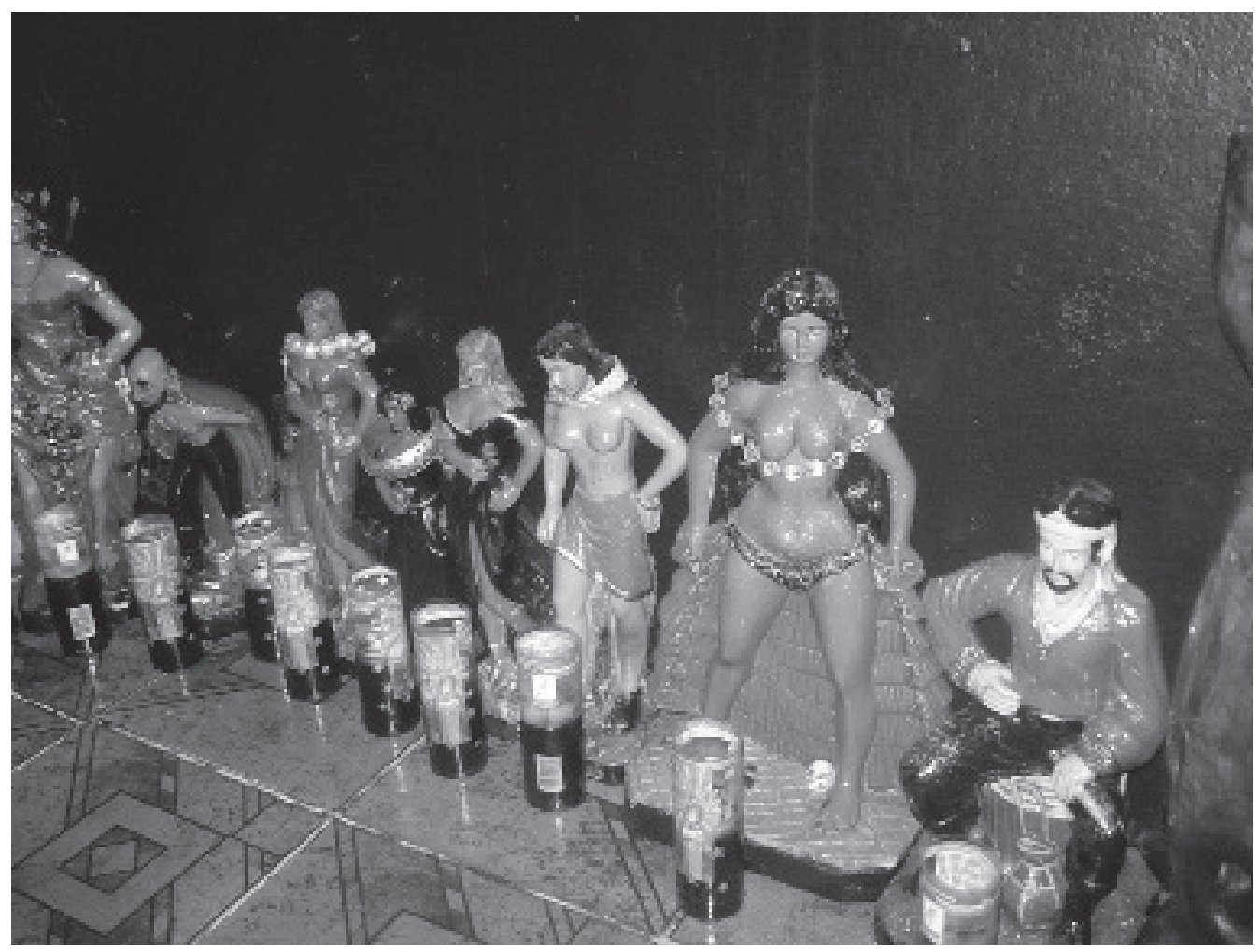

Photo 5. Cafúa, clay statues of different Exú spirit entities in Pai Marcelo's Umbanda house. Photo by Alexandre Riviello.

ane's family that her spirituality was very strong. She claimed that the first time she had heard the sound of the atabaque drums as a child, something in her had changed forever.

After this initiation into Candomblé and after years of devotion she had felt that there was something missing, her spirituality needed something more. She started to study Umbanda, visiting different Umbanda houses and federations. Finally, after some time she found her way to the worship house in Diadema, where we eventually met. Luciane said that now her spirituality was calm, as she had found a good place to develop it further. She specified that the reason for her attraction to this Umbanda house was its spirit entities, especially those of Mãe Pequena Rosana's Zé Pilintra, Pai Marcelo's Ventania and Pai Pequeno Nivaldo's Marabô. She had been accepted as a filha (literally 'daughter', i.e. a developing medium) a year earlier.

On the day of Exú's ritual gathering, the healing session was aimed at her back problems, from which she had suffered for quite a while. During her previous consultation with Zé Pilintra, he had advised her to bring specific ingredients for the healing work, as we see in the above quotation. Luciane did not hesitate to have more faith in Zé than in doctors. She had bought all the required ingredients for the healing ritual and brought them for the Exús that day.

I got to know Zé and his medium Rosana later on during my fieldwork period and learned that he was a very famous healer in Diadema. His services were widely sought, 
not only by Umbanda practitioners, but also by people from different religious backgrounds, even the leaders of Candomblé religion. When I returned to the field three years later I was told that the Umbanda house where Luciane's healing took place had suffered a major conflict, in which half of the worship house's mediums had left together with Zé and Marabô. Many people continuously looked for spiritual services from homes of these entities' mediums. A year after the abandonment of Marcelo's Umbanda house, Zé and Marabô started to receive clients on a roof terrace at Zé's medium home, located in a poor district on the margins of São Paulo. More than half of the mediums left Marcelo's house together with Zé and Marabô, and were now filhos (developing mediums) at the new house, led by Mãe Rosana and Pai Nivaldo (Marabô's medium).

In order to consider in greater depth the material encounters in the human-Exú relationship, I will return to Luciane's experience of her individual spirituality, which she calls the spiritual side (lado espiritual), to the actual healing event and its material and spiritual ingredients, as well as to the materialisation of Exús in the above-mentioned locations, and in human bodies. In the following sections I will look at these elements more closely and discuss the ontological modalities of body-objects particularly as well as the other material and immaterial objects (which in fact become subjects) that Exús are, and the tools which they use in their work and materialisations.

\section{AGENCY, MULTIPLICITY AND IMMANENCE IN THE BODY-OBJECTS}

Like Luciane, many people in Southeast Brazilian metropolises associate themselves with different religions during their lives (see Montero 2001). This also affects the ways many of the religious institutions work in Brazil. For instance, many of Kardec's Spiritist centres work with Umbanda spirit entities such as Preto Velho (African slave) and Caboclo (indigenous Brazilian), many Umbanda houses work with Candomble rituals, and many Candomblé houses work with Exús from Umbanda. This is because people often think that they continue to carry with them the different spirit entities with whom they have become close, even after changing their 'religion' (see also Capone 2004: 178-184). Mãe Pequena, Julia's Umbanda, which I got to know in 2011, is one of the oldest registered Umbanda houses in São Paulo. Its name, Centro Espírita Caboclo Sete Flechas, refers to Kardec's spiritist origins and practices and yet the house is nicknamed umbandomblé (by the house's members themselves), referring to specific Orixá rituals originating from Candomblé. The reason for the explicit 'mixing', Julia explained, was the simple fact that they had affiliated people in the house who asked for rituals in which they could develop their spiritual relationship - not only with their spirit entities as generally in Umbanda, but also with their Orixás, as in Candomblé, as well as to gain spiritual education through Allan Kardec's teachings, as in Kardecist Spiritism. She together with her mãe-de-santo (Umbanda house leader) had decided to study and offer all kinds of services so that the spiritual side of their members could be fully attended to. Thus I would claim that these mixtures, instead of being random or socioeconomically reducible forms of syncretism, in fact have a direct correspondence to the Afro-Brazilian ontological modalities embedded in the notion of the multiplicity and 
refinement of a person. By multiplicity I refer to the constitution of a person in which different ontological beings, such as spirit entities and Orixás, form and co-exist. By refinement I refer to the ritualistic process of spiritual development carried out in places of religious practice, such as in Umbanda houses. In this section my aim is to open up these dimensions more profoundly. Thus, seeing the materiality of ritual practices through this perspective enables us to gain information about knowledge production and agency, in a never-ending (religious) process of what could be called the re-configuring of persons in Afro-Brazilian religious worlds.

This reconfiguring of the person is very much present in the events of spiritual work. One of the key elements in this work is so-called spirit possession, through which the Exús also worked in Luciane's healing session. Zé Pilintra - the other male spirit entity who performed spiritual work - incorporated Rosana as his medium. Rosana, among many other Umbandistas, told me that during the incorporation, when a person "turns towards the saint" (virar para santo) his or her mind can be in a conscious, semi-conscious or totally unconscious state. During spiritual development, she claimed, the mind slowly shuts consciousness down and experienced mediums do not remember anything at all from the incorporation. During incorporation the spirit entities can drink, smoke, crawl, run, dance, shout, talk and laugh in ways that the mediums as conscious people could never do. However, when mediums are at an early stage of their development the incorporation is usually conscious or semi-conscious. When the medium is ready, incorporation erases the medium's consciousness, Rosana explained..$^{15}$

The question of spirit possession has been widely discussed in studies concentrating on Afro-Brazilian religions (mainly in the 'orthodox' forms of Candomblé). Spirit possession has been explained at first as biological, individual and pathological (especially in early texts on Candomblé authored by Nina Rodrigues 1883-1898, and published by Arthur Ramos in 1939 [Goldman 1984: 68]). Soon, by the end of the century, what Goldman calls socio-cultural models emerged, elaborated particularly by Melville Herskovits and later on by Roger Bastide who saw Candomblé as "identical to any social systems, satisfying determined social and individual necessities" (see Bastide 2001 [1958]: 39). Thus, since then the analysis of Brazilian spirit possession was seen (by many authors, such as Peter Fry (1977)), from the socio-political perspective in which the spirits were seen as nothing more than a "mask through which the socio-political mechanisms were occulted" (see also Goldman 1984: 99). In other words the emphasis was on the reduction of the spirit possession phenomenon to either empowerment of subaltern individuals or to the maintenance of the social structures surrounding them. Both of these approaches, the psycho-pathological and the socio-political, have indeed pointed to aspects valuable to understanding Afro-Brazilian religions; however, the problem for both, according to Goldman, resides in their reductionism and lack of explanation of the phenomenon itself, which he sees as a symbolic system of construction and maintenance of the personhood and its equilibrium (ibid.: 105, 191-192). I follow Goldman in his critique in my perspective on human-Exú relations, but instead of limiting it to spirit possession in human bodies, I consider that the idea could be extended to all forms of intercommunication between people and other significant beings in AfroBrazilian socio-cosmology. Thus, as I will show, through the examination of materiality in ritual communication we will see that the so-called possession, or the dynamism of actualisations of immanent potentialities is actually a permanent existential stage in all beings. 
Thinking about the concept of person in Umbanda, spirituality as well as medium potentiality are seen as essential attributes in being human, as Pai Marcelo puts it, "for being a medium you only need to be alive". In Umbandista autobiographies, a common feature is early childhood experience, in which a person is introduced to the spiritual side (plano espiritual). For example, it is very common that a child who cries a lot, constantly has bad dreams or otherwise behaves in an unexpected fashion is taken to a spiritual consultation in some religious place of practice (as we saw also in Luciane's example). The reasons behind these physical or psychological problems are seen as spiritual. In order to take care of the situations people have often gone to the doctor first but then when the problem continues, have been guided, (often by doctors themselves) to a spiritual consultation. Ghosts and bad dreams are not 'rationalised' away as products of the imagination but are interpreted as a spiritual imbalance. Thus all the Umbandistas I have interviewed, despite their different emphases in ritual practice, share the same idea of the world in which the spiritual side is an essential part of all existence, through its material and immaterial domains.

According to Umbanda practitioners, people are never born alone. They are born with guardian angels, different spirit entities and Orixás. These non-human dimensions of human selfhood do not necessarily make people conscious of their existence. However, just as Sansi (2013: 84) observed in Candomblé, signs of these different (nonhuman) attributes of (a human) person can emerge during one's life and in some cases the spirit entities need to evolve and the Orixás might need to be taken care of. Ariane, a 27-year-old actress, for instance, explained that when she moved to Rio de Janeiro she immediately started to act in a deranged way: she talked loudly and often ended up physically fighting and arguing with men in the streets after partying the whole night in the Lapa district. She felt that she could no longer control herself, and that she was constantly hovering on the edge of sanity. What she eventually became aware of was that it was actually her Maria Mulambo, who had entered "in front" (está na frente) of her appearance. This is why her actions were uncontrolled and why, in order to calm down, she needed to develop her spirituality, that is, to take care of her Mulambo and give her space to work properly.

Moreover, in Umbanda all mediums are sons or daughters of Orixás. Orixás are not, however, gods. In fact Pai Marcelo explained that the difference between God and the Orixás is that God is the origin of everything that exists, while Orixás govern the elements of nature, and yet simultaneously they are these elements. Thus Orixás are not Gods or divinities in the sense that modern Euro-American thinking would like to categorise them. They are nothing more or less than Orixás, and in my view should also be theorised as such. Consequently, the same can be said of Exús and other spirit entities and non-human beings in the Afro-Brazilian worlds.

Orixás, in a similar manner than the spirit entities, manifest themselves on earth through mediumship (mediunidade) in both human and non-human, material and immaterial things, and in that way form the natural vitality of the lived worlds of my interlocutors. According to Pai Marcelo, all things and beings are born, formed or made out of elements that originate from energies of a specific Orixá (see also Goldman 2011: 116). All things come into existence in the energetic flows (linha or literally 'line') of Orixás and the balance of this essential interconnection can be re-configured through materialisation and material manipulation of the specific attributes in objects, 
in humans and in non-human beings. Spirit entities, like people, belong to the lines of Orixás. Many Umbanda devotees and clients do not, however, bother with this type of theorisation about the relation between Orixá and spirit entity. Both of them are simply taken for granted, as natural things - in both senses of the word. Umbanda practitioners simply feel that they know and are more intimate with their spirit entities, as they are with those whose spiritual work they are familiar with in practice. Some Umbandista practitioners, however, (like Luciane and the devotees in Julia's umbandomblé), feel that the intimacy of both Orixás and spirit entities is significant because of the life trajectory that has for some reason revealed both of them and in that way made the intimacy of both beings more concrete.

This type of multiplicity and vitality in an individual (and other objects) is present in all situations in Afro-Brazilian religious worlds. Goldman (2011: 116) argues:

a certain 'vitalism', rather than 'animism' is at the heart of Candomblé [...] the modulations of a single force called axé (similar to other anthropologically familiar notions such as mana and orenda) make up everything in the universe according to a process of differentiation and individuation. The unity of this force guarantees that everything participates in everything else, but its modulations are such that there exist levels of participations.

Even though the concept of axé was not theorised much among my interlocutors in Umbanda, I could clearly perceive this type of ontological 'vitalism' related to the discussions on the spiritual-material domains in people and other things and beings. ${ }^{16}$ For instance, when an Umbanda practitioner enters a different space, the spiritual side, i.e. the spiritual attributes (related to spirit entities and Orixás) of selfhood react to the new situation. This can emerge as the sudden fear experienced by Iemanjá's 'daughters' when going to the beach, or uncontrolled partying as in Mulambo's case. This is also one significant reason why people associate themselves with different religions, worship houses and churches until they find a place where they will, temporarily or permanently, feel at home, i.e. get into balance with the surrounding energies, as Luciane explains. When entering the Umbanda houses the person's vibrations are considered to either 'match' the house's spiritual context (corrente espiritual) or not, depending on how their immanent qualities are received and treated. The individual process of looking for the right energetic ambience, in terms of visiting various Umbanda houses until finding the right one, is an essential feature in the autobiographies of Umbanda mediums.

Another example of this kind of reaction was shared with me by Silvia, one of the mediums who followed Zé Pilintra to his new Umbanda house. Silvia explained that sometimes during the incorporation in ritual gathering, she feels in her body that some of her Exús are trying to take over, although usually Rosa Caveira, the most evolved of her Exús, does not let the others enter. One of these other Exús Silvia carries, and loves passionately, is called Cobra. Cobra came to her in a dream a couple of years ago and according to her, stayed in her room for one week. During that time she did not know what it was. The leader in the Umbanda house where she was spiritually evolving at that time, claimed that Cobra was a bad thing, and they had tried violently to extract it from her body. However, after that, everyone present in that Umbanda session, except Silvia and her cambône (spirit entity's human assistant in rituals), became very sick. She realised that Cobra was very angry about what had been done and was actually trying 
to tell her something. So she went to another Umbanda house to see what they would make of him. There the Umbanda leader and other mediums received Cobra with the highest respect and Silvia understood, as she had already assumed, that Cobra was one of her personal Exús. Since then, Cobra has been working every now and then, or whenever Rosa allows, Silvia explained laughing. When Cobra comes, she continued, her whole body is transformed, as he comes crawling on the ground like a snake.

Even within the Afro-Brazilian religious universe in a larger sense, it is common to hear that people who were looking for spiritual advice for instance in Candomblé worship houses, were sent by the Candomblé leaders to look for Umbanda or vice versa, referring to the work that should be done according to the immanent qualities of individual energetic vibrations that are natural, albeit individually particular, in all humans.

\section{MATERIALISATION OF EXÚ: RITUAL OBJECTS IN KNOWLEDGE PRODUCTION}

The process where an Exú becomes known is related to the ontological need of both beings involved: people and Exús. It is commonly known among Umbanda practitioners that spirit entities materialise because the person who carries it needs to evolve his or her spirituality, but also because the spirit entity itself needs to carry out charity work. Some say that the spirit entity itself is also evolving through materialisation. Exús particularly are often considered to have spiritual debts because of what they might have done during their lifetimes. On the human side the need is, as stated above, to balance their spiritual-material equilibrium aiming at refinement. Thus, working as a medium is considered dedication to help others, making people closer to the spiritual world and eventually to a sense of balance.

Not all spiritually developing Umbanda practitioners feel the need to affiliate themselves with a worship house, instead some work with spirit entities in their homes. Moreover, many people I have talked with consider their need for development as a kind of spiritual heritage that has been passed down from earlier generations. The spiritual heritage does not have to come from the same origin, but when spirituality has been developed in their family, it is often a reason for people to think they also have a need to develop it one way or another.

Despite the reason why one should get started with the process of spiritual development (instead of simply relying as a client on the work of the spirit entities), people in Umbanda affirm that the spirit entity has in several logical ways made it clear that it wants its carrier to develop. This is because the Orixás and spirit entities are already there, as Sansi (2013: 83-85) observed about Orixás in Candomblé. Thus, suddenly the immanence of different things, human and non-human, becomes active and requires the materialisation of Exú or other spirit entities.

In practice Exús materialisation is primarily a very material event. Exús like Zé Pilintra, Exú Marabô, Rosa Caveira and Cobra have all at first given signs of their existence in several ways and little by little have revealed themselves through material and immaterial objects. In the previous section I explained the ontological modalities related to body-objects, the same logic of immanent potentialities is apparent with clothes, drinks, smokes, hats, among other things that are part of who the spirit entity existentially is. 


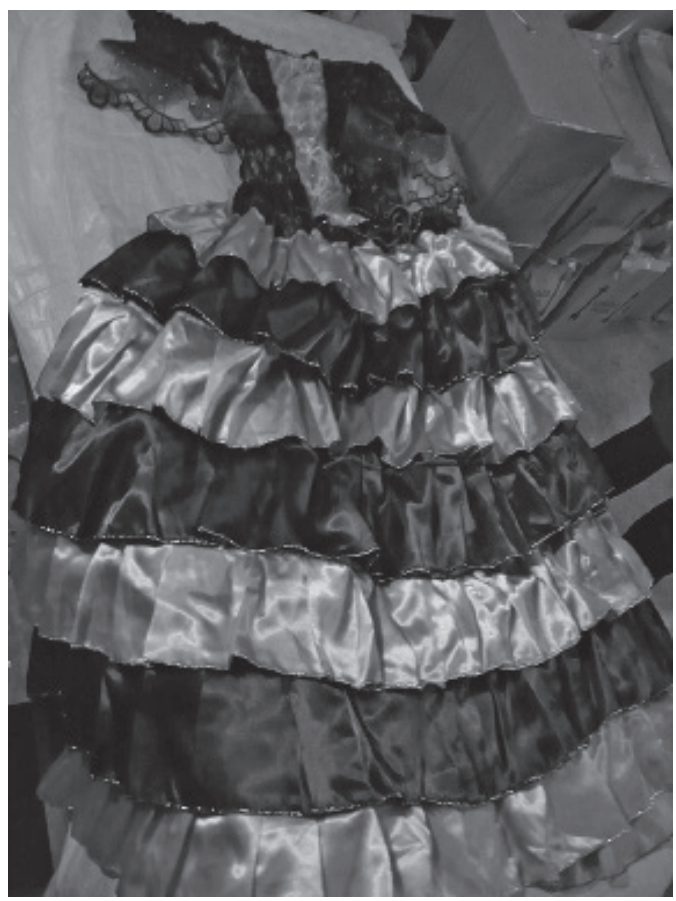

Photo 6. Female Exú Sete Saias dress sold in ritual shop, city of Diadema. Photo by Alexandre Riviello.
Through these objects the spirit entity's personality and habits become recognisable. In other words, these materials are part of the objectification of the spirit entities the developing medium goes through. The spirit entities appear at first in dreams, in visions, as voices and as intuitive knowledge. They are part of their medium's sub-conscious and during the evolvement process they become recognised as separate beings, or ontologically significant others, as I will point out further on in this article.

During my fieldwork I heard many stories about objects that people considered special. Many of these objects related to the knowledge production process, prior to the materialisation of Exús. These 'mediator' objects had come to them through dreams, intuition or as gifts. The objects wanted to be bought or made because the spirit entity's immanence had connected to them, as well as to the human medium's consciousness, to which it is ontologically linked. In other words, the spirit entity who is already there, changes from an immaterial to a material form. The agency in this process is all about immanence as well as about the relations/networks between these different ontologically connected things.

For instance, many of the Exús I became familiar with had informed their mediums what kind of clothes they wanted to wear in dreams or in person while manifesting themselves in the medium's body. Sometimes the style of these clothes originated from the time the spirit entity lived its human life. The specific requirements about the colours, ornaments, materials and all kinds of detail varied to such an extent that in one ritual gathering I never encountered two Exús which looked exactly the same. In order to dress up their Exús, people look for esoteric shops or special dressmakers. One dressmaker who specialised in making clothes for spirit entities explained to me that people often order spirit entities' clothes according to the wishes the spirit entity has expressed to them while taking bodily form in dreams or in voices. However, during the process of making, she suddenly receives more detailed information from the proper spirit entity and in the end the cloth can come out very differently compared to the original request. It is common, she said, that while expecting the spirit entity's outfit to be ready for ritual use, the medium has also acquired more detailed information from the spirit entity and becomes nervous, thinking that the clothes cannot be used, as it will not please the specific preferences of the spirit entity. Usually this concern, however, is ungrounded, as the dressmaker has already been able to satisfy the spirit entity's complete wishes without having communicated with the medium. I heard sev- 
eral similar stories in relation to ritual necklaces, statutes, and other tools of spiritual work required by Exús.

Material objects also have a special role when a medium prepares him- or herself for ritual incorporation. Rosa Caveira's medium Silvia explained that the preparation for spiritual work with the spirit entities starts one day before at the medium's home. She prepares herself by avoiding red meat, sex, and dark clothes, because these things might interrupt one's spirituality, as their spiritual influence is 'strong' (pesado). Dark clothes, for instance, not only attract the Exús in Umbanda terreiros but also all kinds of dead spirit (egun) that wander around and can harm the spiritual development of the medium. Sometimes Silvia sleeps on the floor on a bamboo mat (estera) one night before the ritual gathering and takes special herbal baths that protect her during the Exús' incorporation. The day of the ritual gathering she always senses that the spirit entities are coming nearer. They are already with her for 24 hours like shadows, she said, but when the ritual gathering (gira) comes closer, they start to enter her more strongly.

In a way, the Umbandista perception of materialisation is very close to what Karen Barad has claimed to be a post-humanist account of performativity. Barad states that this view challenges the positioning of materiality as "either a given or a mere effect of human agency". In her "agential realism" materiality is seen as an active factor of materialisation, seeing that "nature is neither a passive surface awaiting the mark of culture nor the end product of cultural performances". (Barad 2007: 183) Both ontological materiality in Umbandista perception and the non-anthropocentric stance in posthumanist manifests challenge Western dualist approaches, which have emphasized the distinction of nature and culture over the last few centuries, positioning humans at the centre of the universe. Barad states that the primary units of ontology are phenomena that, according to her, are "dynamic topological re-configurings/entanglements/ relationalities/(re)articulations of the world". She argues further on that "the primary semantic units [...] are material-discursive practices through which (ontic and semantic) boundaries are constituted". The dynamism, she states, is in fact "agency - not an attribute, but an ongoing re-configuration of the world". Thus, the "turning towards the saint" in the Umbandista world, can be seen - following Barad's concepts - as a form of "agential intra-activity" in a world where everything is connected through spiritual and material domains. (Ibid.: 141)

THE POWER OF MATERIAL AND IMMATERIAL

TOOLS IN EXÚ'S WORK

As we have seen, material objects are significant in knowledge production within the Exú's materialisation process. Now, getting back to Luciane's healing session performed by the two Exús, based on the same logic I will show how these ingredients of spiritual work (like cachaça, chicken blood, etc.) also work as part of transformative healing. Here (as in the previous section) I do not analyse each object separately, but look at them through their ontological category, namely as tools (ferramentas) of spiritual work.

In the beginning of my fieldwork in 2011, I visited several shops that sold ritual materials for ritual purposes in Umbanda and other Afro-Brazilian religions, as well as to individual practitioners of similar rituals. One São Paulo based stockowner who 
had a wide national and international distribution of ritual objects explained that all of the objects sold in ritual shops had their special purpose. He explained that all herbs, incenses, candles, beverages, necklaces, clothes, stones, etc., sold in these shops have specific potentialities and attributes embedded in their agency and efficacy. Goldman (2011) and Arnaud Halloy (2013: 138) have observed similar phenomena in relation to materiality in Candomblé and emphasised the ontological potentialities in the immanence of certain ritual objects that are ritually 'made' or 'charged'. The notion of potentiality is indeed a very accurate approach towards materiality in Afro-Brazilian rituals, in which what is at stake is not the creation of something new, but the activation of potentialities, powers and capacities that already exist - based on the same logic that we saw in relation to human-objects.

However, in Umbandista worlds, not all objects have gone through ritual charging, although they are still used by the spirit entities in Umbanda rituals. The purpose of the ritual objects to which the stockowner referred, is in fact an essential dimension that links the material and the spiritual to each other and through which the balance between these two sides can be worked. Candles, for instance, sold in ritual shops or regular supermarkets, whether they are made for ritual purposes or not, carry a capacity, potentiality and power within them, simply because of what they are. It is not only due to the candle's flame - that is considered a point of light through which the spirits of all kinds can be attracted in Umbanda - but also, and essentially, the colours themselves. Thus a red, half-red half-black, or black candle bought by an Umbanda practitioner for Exú work (as in Luciane's case), can be any candle from these colour options. Thus, colours themselves have attributes, potentialities, powers and capacities to attract Exús and Pomba Giras. These colours are theirs, and simultaneously they partake of these colours, or more precisely, their vibration is transmitted through and within these colours. Similarly, as I explained in the previous section about the medium using light clothes as a preparation for ritual gathering, many mediums attending Exús' ritual gathering come dressed with red and black clothes, specifically because the colours attract Exús, and in this way the consultation or spiritual work performed by the Exús to promote wellbeing is considered even more efficient. On the other hand, the clients - people do not generally know enough about Umbanda - are sometimes advised to come in light colours so as not to attract Exú energies too strongly - meaning that they could end up incorporating Exú without any proper preparation, which would not necessarily be a pleasant experience.

Immaterial objects in ritual communication such as the smell of incense, ritual songs and drawn symbols are also considered effective because of their existential attributes. Ritual songs, for instance, are considered a very powerful way of evoking spirit entities. Such songs are learned from spirit entities and today also from CDs and the Internet. The Umbanda practitioners I met did not want to sing pontos just for fun, as that might confuse the spirit entity and even evoke dangerous situations. Drawn symbols are usually made by the spirit entities when they arrive (and are incorporated into the medium's body). They are like a spirit entity's signature, by which (among other things) they can be recognised. The herbs used for incense are also effective as such. The Umbanda mediums emphasised that it is always good to use fresh herbs and many people grew the herbs in their homes. However, taking into account the busy lifestyle in the metropolises, I saw that dried mixtures of ritual herbs, as well as incense, was sold in ritual 


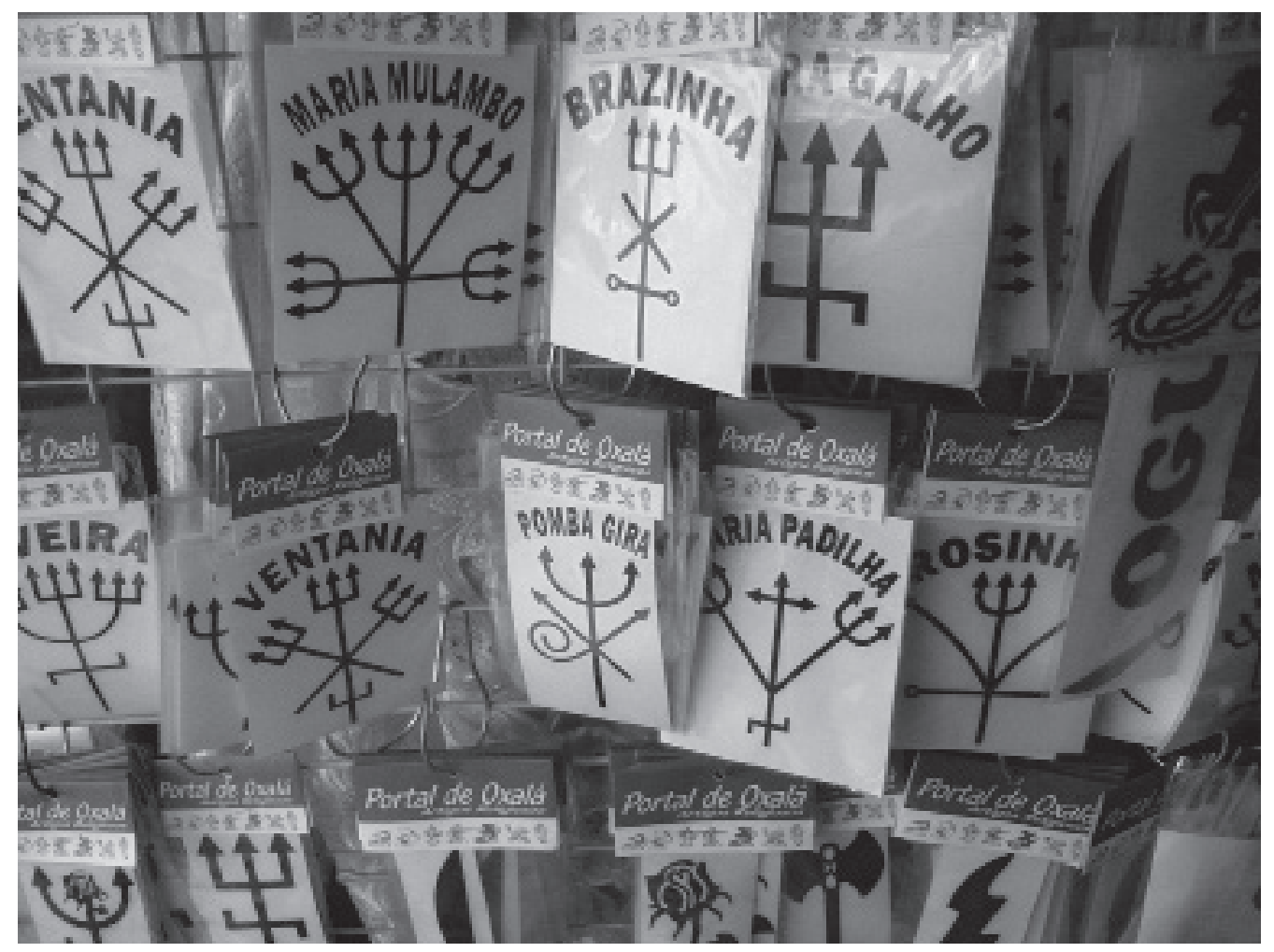

Photo 7. Pontos riscados - stickers sold in ritual shop, Diadema. Photo by Eleonora Lundell.

shops, on many newspaper stands and in supermarkets in urban areas and were used by Umbanda people as well as by many others. These bags and boxes carry the name of the herb or alternatively only the purpose of its use, such as "open the pathway" (abre caminho), "break the witchcraft" (quebra feitiço), etc.

As mentioned above, some Afro-American religions scholars (for instance Goldman 2011; Holbraad 2012; Halloy 2013; Sansi 2013) have written about ritually charged objects. These objects are more powerful than other objects. Their powers are often protected and controlled by restrictions. One of my interlocutors, Pai Ivan, Umbanda leader from São Paulo, for example, does not let other people touch his ritually charged objects as this might, according to him, be dangerous. Anyone can, of course, buy different things that are commonly used for and by the Exús for example. According to Ivan (and other Umbanda practitioners) this is considered very dangerous, as the Exú will respond to a ritual performed with these ingredients, although without further knowledge the outcome of this action could become very unpleasant. Even though all of the above-mentioned scholars agree that the 'making of the saint' (i.e. the materialisation of Orixá) in Candomblé, is a question of the saint being discovered, they also seem to agree that powerful ritual objects only work after a specific ritual preparation. The notion of 'made' objects (ritually made power objects like Exú statues, guia necklaces and firmezas appearing in the above description of Exú ritual gathering in Pai Marcelos Umbanda), concurs what Holbraad, Goldman and Sansi have written. However, the rest of the 
objects (the given), ritually charged or not, are in my view also (spiritually) powerful, as they are considered to have been constituted by one or many qualities and thus their agency and efficacy is related to their immanence, that is, enchanted (or charged) by nature itself. These implicit or explicit potentialities of material and immaterial objects (such as cigarettes, clothes, beverages, aliments, colours, rhythms, etc.) can be activated by human and non-human beings at any time. Moreover, both of these object groups' efficacies are based on the constitution of the ontological spiritual-material dualism in which what is at stake more precisely is the agency and modifiability of immanence.

During the process of Luciane's healing ritual, as in any spiritual work in Umbanda, the ontological status of used objects (tools) changes. During the spiritual work they become charged by the negative energies that were taken out of the healed person. Usually Umbanda people claim that the objects used have to be taken care of by a process called dispatchment (despacho). All of the material remaining has to be taken care of in a secure manner, because if they end up in the wrong hands the negative energy that was charged in them, could be used for negative actions. Some Umbanda practitioners are very careful not to throw anything in the garbage can, not even the plastic cover wrapped around candles. Depending on each work carried out with that candle, its remains have to be dispatched properly at street corners, in bushes, buried underground, etc. Despite the different procedures people have in their home rituals, in worship houses the remains are always thrown away ritually.

\section{MATERIALITY AND COMPANIONSHIP}

Among the Umbanda practitioners I came to know during my fieldwork, the spirit entities of highly evolved mediums, like Zé Pelintra in Luciane's healing, are experienced in a very mundane manner as members of social networks. People who have known Zé for a long time have heard him telling bits and pieces of his lifestory (while he was still in human form). Apparently Zé was a gambler and spent his time playing cards and chasing women. The mediums assume he lived in the early 19th century, as sometimes he talks about the time of slavery. It is known that a fight over a woman finally killed him, as a jealous man shot him, leaving bullets in his leg. That is why, people say, he still hobbles. After turning into a spirit entity, Zé's special expertise has been related to health and employment issues. According to his medium Rosana, Zé works nearly every day attending people from their Umbanda as well as many Candomblé devotees, even Candomblé leaders and other people who are more Catholics and Spiritists than into Umbanda, claimed Rosana. Zé is well known in Rosana's neighbourhood and, according to her, even some of the local Pentecostals salute him with respect when he walks in the streets outside the worship house. Despite the negative Pentecostal attitudes towards Umbanda, the local Pentecostals perhaps do not think negatively about Zé because he is very well educated and dresses in a sophisticated manner, Rosana explained.

Rosana has been working with Zé Pelintra for almost 20 years, and now talks with him directly every day. She claims that when Zé is near, she sees him in front of her without having to incorporate (to take the bodily form). At the beginning of her development the communication between them was more through the messages he had sent 
during the incorporation, but today, as he is very developed, they can communicate as people, according to Rosana. Although they are good friends, their personalities and preferences still differ quite radically. For instance, Zé loves to eat raw liver while Rosana detests it and claims that she would immediately vomit if forced to eat such a thing. Zé also loves to drink cachaça and can spend long hours talking with people as he loves attention. Rosana, on the other hand, saw herself as a reserved non-drinker. In addition to Rosana the one person who knows Zé profoundly is his cambône, Rita, who describes Zé as a friend, father and sometimes she jokes that he is even her husband. She claims to love him profoundly and admires his ability as a healer. Zé is a lovely person, she says, but when he sees that people are not sincere he immediately becomes furious.

The other famous spirit entity, Pai Nivaldo's Exú Marabô, has broadened his friendships even to other non-human beings from other religious contexts. Thus he is well known and respected in the other Afro-Brazilian ritual house, Tambor de Mina, ${ }^{17}$ nearby. One spirit, Boço Claudio (an encantado incorporated in Pai Gustavo's body) told me that he likes to visit different Umbanda and Candomblé houses in order to meet his friends, who are, for example Pai Nivaldo and his Exú Marabô, as well as many other people and spirit entities whom he has come to know during the last twenty years.

In my fieldwork I observed that companionship is also experienced through ritual objects, which, as I have shown, are some kind of mediators in these relationships (in materialisation and spiritual work) through their immanent potentialities. People express love and caring towards the objects their Exús use, cherishing the clothes, gifts, statues, pipes and other things. In Umbanda

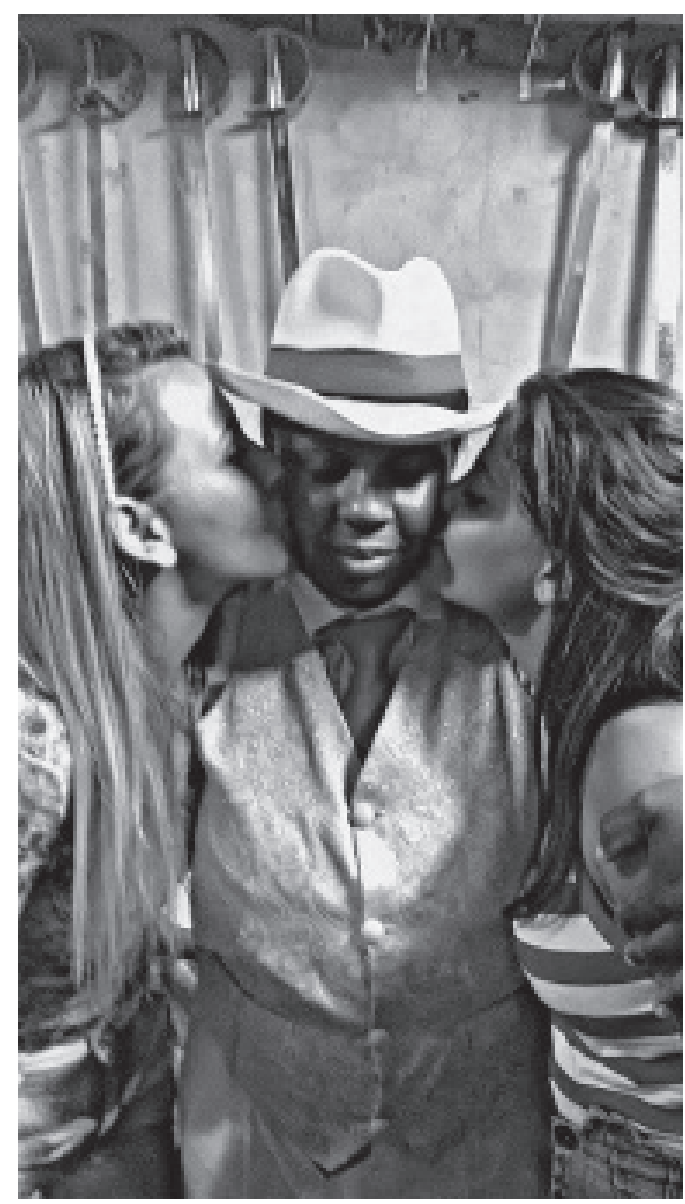

Photo 8. Zé Pelintra with two mediums. Photo by Eduardo Araujo da Silva.

medium houses I saw separate wardrobes for the spirit entities, as well as home altars where significant spirit entities objects were kept.

At the experiential level it seems that Exús are like people but of different 'species', thus they are spirit entities that can be materially present at their firmezas and houses, yet they are like the wind, which can blow anywhere and in many places at the same time. They follow people and see everything that is happening. They can appear in front of people and make them change their ways and affect their choices. Thus we 
might see Exús (among other spirit entities) as ontologically significant others. According to Haraway (2003: 24), who has written much about significant otherness and companion species, the primary ontological unit is a relation. This kind of approach in the context of human-Exú relations seems quite radical, as it forces us to take Exús and other non-human spirit entities, as well as Orixás, seriously. This approach in my view is however relevant if the aim is to understand agency within the different ontological modalities of materiality. So-called material semiotics might well offer tools for us to think further about the non-human in social interaction among Umbanda practitioners. Bruno Latour's ideas in ANT (actor-network theory) were based on the idea of de-centralised agency, which could be defined as the "semiotics of materiality" that is "symmetrical with respect to human and non-human agency" (Law 1999: 4; Knappett and Malafouris 2008: xi). The actor is defined through its capacity to make a perceptible difference. These active entities are seen as being relationally linked with each other in webs, making a difference to each other, bringing each other into existence. In the same vein, material semiotics goes beyond linguistics, claiming that "entities give each other being, that they enact each other" (Law and Mol 2008: 58).

Moreover, Haraway has demonstrated in her inter-species analysis how people actually 'become' with dogs and dogs 'become' with people (Haraway 2003). In Umbandista worlds Exús are as real, equally loved and lived with, as for instance the human-dog relationships Haraway has studied in Western societies. Thus, ontologically the otherness of Exús is equally significant, as they are material, they are persons and they are actors, even though not in the same biological sense as humans. In fact the ontological status of Exús is simultaneously human and non-human, material and immaterial, and thus the categorisation of an Exú through such concepts as spirit or ancestor would require a radical epistemological extension. As ontological entities, Exús indeed have an effective multi-layered agency in the lives of people who share their history, routines, plans, hopes and desires with them, and most importantly the material attributes in their immanence. Thus, as Haraway has stated about being in the world in general, I would say that for people I have encountered in Umbanda houses in particular what is at stake is indeed a process of 'becoming with' (ibid.: 16). Thus, any kind of anthropocentric theory would inevitably fail if it maintained that a faithfulness to 'Native' experience would be the key point in analysing agency and materiality among mediums and clients of contemporary Southeast Brazilian Umbanda houses.

\section{CONCLUSION}

Both modern western Christianity and scientific materialism were built upon a denial of the spirits in things as well as - despite the latter's tendency to associate the material with the concreteness of 'facts' - common understanding of materiality as ultimately defined by the socio-historical process of abstraction of the spiritual from the material (Espirito Santo and Tassi 2013: 2).

The above quotation points to the post-dualist critique that is part of the post-humanist account that questions the anthropocentric perspective of agency and materiality. This discussion has been in dialogue with ethnographic thinking about materiality in different ontological contexts. Holbraad (2012b), for instance, has proposed the establishment 
of anthropological 'objectology' in which all things could be looked at and theorised as such, extending the borders of concepts, as well as giving birth to new ones. In this article I have tried to understand materiality in the ritual communication between people and Exús, at the same time keeping in mind the epistemological challenges embedded within the concepts (religion, spirit, ancestor, ritual object) we commonly use in order to talk about this kind of phenomenon.

The concern of the incapability of Western epistemological dualisms to explain contemporary religious worlds has been expressed by several scholars recently. More precisely, what is at stake in the discussion when talking about the agency of spirits or ritual objects, for example, is the question of evidence. Concerning the epistemological problematic of evidence in the anthropology of religion Webb Keane $(2009,112)$ asked if it is possible for us to "define religion in a way that takes seriously the perspective of its practitioners and can still guide research across contexts without inviting paradox?" Keane suggests an attention to religious practices "more generally, attending to their forms, pragmatics and the semiotic ideologies they presuppose" (ibid.). In line with these ideas, my observation about the material and immaterial evidence of the humanExú relationship presented in this article has led me to the realm of Afro-Brazilian common sense in which evidence of Exús among other non-human beings, "lies not in the illusion of the really 'real' but in ways of being, perceiving, and knowing" (cf. Blanes and Espírito Santo 2014: 26).

In this paper's introduction I emphasised the importance of attending to 'the voices of things', while thinking about the materiality through which people relate themselves to Exús (cf. Holbraad 2011). In trying to make sense of this specific human-Exú relationship, I have tried to trace the voices of different material and immaterial things that seem to form its essence. Aiming to describe and open up the 'ontographic stories' of people and the different material (such as candles, clothes, guia necklaces, chicken blood, etc.) and immaterial things (such as colours, songs, and ritual drawings) that have significant roles in the ritual communication, I have pointed out that, within the events of spiritual work and spiritual development, the relationship is firstly about the way a person is perceived in Umbanda worlds. The agency in an Exú's work is worked through body-objects where a person 'turns into a saint', that is, lets another attribute into his or her multiple existence to govern the consciousness and actions for a certain period. The multiplicity of a person is in constant dynamic process, which can be controlled by spiritual development (desenvolvimento) in different religious institutions, for example in Umbanda houses. This process of re-configuring a person is related to the second aspect I have explored in this article, specifically the materialisation of Exús. This materialisation is enacted through a process of knowledge production in which non-human material objects become key actors through their ontological immanent potentialities. In spiritual development the Exú becomes known through the different objects that reveal its characteristics to the carrier medium and others in the same social network.

Thirdly, I have pointed out that the relationship is about transformations (healing, getting a new job, finding a new love, etc.), which ontologically are in fact re-configurations, enacted through the spiritual work Exús perform. The material object Exús use in this process enact the reconfiguration of spiritual-material balance, again, through their immanent potentialities, the "given" and the "made" (cf. Sansi 2013). This never-ending 
process of re-configurations is possible through the connectedness of all things and beings that become in the world through their immanent attributes. Thus, in Umbanda worlds, the power of different ritual objects is about their nature, or perhaps more precisely, their natureculture.

Finally, the relationship between people and highly developed Exús is about social networks, thus companionship, friendship, love, trust and admiration are at stake when Umbanda people describe their relationship with Exús. If we look at the practices of this companionship, we might say that the companionship between humans and nonhuman Exús is very much a material one. Thus the significance of materiality in this particular companionship is not only symbolic or representative, but also, as shown above, primarily re-configurative.

Based on these observations, I see that to describe Exú as a spirit or an ancestor is not accurate. According to the experiences of people I encountered in Umbanda houses, an Exú is in many ways a material(ised) companion with whom daily life is shared. The material and mundane part of this ontological existence in fact challenges the transcendentalisation of Exús. Thus, the spiritual-material dualism does not refer to two distinct domains dwelled in by different groups of beings, but to the existential constitution of all things, which carry both of these dimensions within them.

Thus, in Umbanda worlds, we have seen that, particularly through the notion of Orixás, religion is largely a question of nature (rather than of culture). The essence of humanity is mainly a question of a multiplicity of non-human powers and attributes (instead of anthropocentric dichotomies). As we saw in the case of highly developed spirit entities like Zé Pilintra, the ontological position of Exú also closely resembles an inter-species relation, rather than those commonly described in religious contexts that talk of the radical alterity placed between the world and transcendence. Therefore, I suggest that by connecting the 'ontographic' method with Haraway's (2003: 24) post-humanist account on ontology - as a question of how material-semiotic relations between significant others is constituted - we might get closer to a more accurate conceptualisation of the materiality of religious practices in Afro-Brazilian worlds.

\section{NOTES}

1 Among my interlocutors Exús are referred to in Portuguese with more general concepts such as entidade ('entity') or guia ('guide'). Thus, acknowledging the absence of better English translations, I use spirit entity (instead of mere spirit) attempting to give more emphasis to the ontological materiality and agency of Exús.

2 All the names of people referred to in this article have been changed.

3 The Portuguese word gira in this context means ritual gatherings/cults performed in Umbanda houses. The verb girar ('to spin around') refers to the way mediums move their bodies in order to be possessed by or turn into the Umbanda spirit entities they 'carry'.

4 Spirit entities 'come from' (vir) and 'work' (trabalhar) on the two sides of existence: the left (esquerdo) and right (direito). Exús are known for being specialists of the left side. Depending on the situation, the left is sometimes also worked by Zé Pilintras among other right-sided spirit entities, such as indigenous Brazilians (caboclos), ex-African slaves (pretos velhos), sailors (mariheiros), children (crianças), cowboys (boiadeiros), Bahian people (baianos) and gypsies (ciganos). The rule of who works on which side can vary from one Umbanda house to another; however, Exús themselves never work on the right side. 
5 In Portuguese the term umbandista refers to a devoted practitioner of Umbanda. The different groups attending the Umbanda houses I have studied are: the leaders 'Mother' (Mãe) and/ or 'Father' (Pai); the leaders' assistants 'Little-Mothers' (Mãe Pequena) and 'Little-Fathers' (Pai Pequeno); ritual musicians (Ogã); the mediums (medium) and the spirit entities' assistants (cambône). The ritual audience (assistençia) are the non-devoted clients attending public ceremonies in Umbanda houses. Umbandistas (as well as practitioners of Spiritism and Candomblé) are sometimes called macumbeiros in an ironic sense by themselves, and in a pejorative sense by outsiders. In popular language (despite its original meaning as a specific ritual drum) macumba means 'spell', 'magic' or 'black magic'. The negative weight of the term depends on the context of its usage and the person who uses it.

6 The anthropological studies of Afro-Brazilian religions have been largely interested in the question of the African influence in Candomblé, but also in Umbanda. (For more detailed information about this discussion, see Capone 2004.)

7 By the term 'body-object' I refer to the ritual use of human bodies during the act of incorporation ('spirit possession') of spirit entities and Orixás.

8 Some anthropological studies - influenced by the so-called re-Africanisation of Afro-Brazilian religious and anthropological studies - posit Umbanda's origin and formation much earlier in history than many Umbanda practitioners themselves (Engler 2012: 16-17). In reference to the centrality of ancestors in Umbanda practice, some studies claim that Umbanda is not a degenerated form of observance. Whereas Candomblé inherits ritual knowledge from the Yorubas, Umbanda in fact originates from a different cultural tradition, specifically that of the Bantu, which is considered to have had more influence in Southeast Brazil during the slavery period (ibid.: 22). In the last centuries in southeastern Brazilian cities the Afro-Brazilian religious practice was known as Macumba, (see also note 5) and thus from this point of view Umbanda has been seen as its (re)formation. Most studies on Afro-Brazilian religions have concentrated on the Northeast and have however seen Umbanda as a degenerated cult because of its explicit combinations of different religions (Capone 2004: 16).

9 Orixás are entities that originate from West African Yoruba culture. Orixás are often described as gods or divinities, but the contextualisation of these entities through these concepts is complicated and will be further discussed in this article.

10 Kardecismo, Espiritismo, Espiritismo Kardecista are names referring to a 'spiritist' doctrine captured in specific books authored by Allan Kardec, a spirit incarnated in a scientist Leon Rivaíl, who lived in 17th-century France. The 'science of the spirits' is widely acknowledged, respected and practiced in Brazil as well as in many other Latin American countries. It is popular especially among the middle class population and has greatly influenced the different forms of popular Catholicism and Afro-Brazilian religions, such as Umbanda. In Spiritism the central idea relies on spirit reincarnation and spiritual development (of both spirits and people), which is achieved through different forms of charity work. According to the many adepts of Espiritismo Kardecista, the difference between their spiritual work compared to that carried out in Umbanda and Candomblé lies in the type of spirit involved. Thus, Espiritismo Kardecista usually only works with what they consider as highly developed energies/spirits, whereas Candomblé and Umbanda from their perspective deal with lower or more "primitive" energies. Thus Exús, for instance, are usually seen as down-to-earth energies that can easily cause harm as they have not given up their material lives. (See Capone 2004: 90-92)

11 Macumba is a term often used as an accusatory attribution to practices that are objects of fear or derision, an ascription attributed to practices deemed to be linked to witchcraft of one sort or another. At the same time, however, Macumba can be used as a generic term that refers to all Afro-Brazilian religions [...]. (Cardoso 2014: 93)

12 The portuguese word terreiro means literally a yard, and is used in Afro-Brazilian religions in reference to the buildings and the yards around them, in which the rituals are performed for different non-human entities. 
13 The Umbanda leaders are more commonly addressed as Father (Pai) and Mother (Mãe), instead of the longer versions: pai-de-santo and mãe-de-santo.

14 The interview with her, as with my other informants, was roughly divided into two parts in which the main topics were religiosity in the different phases of life trajectories, as well as the personal relationships with ritual objects that people and their spirit entities used in rituals and those they carried around or had stored in their homes (spirit entities clothes, images, stones, cups, statues, etc.). I had asked people to bring some significant objects to the interviews that were held in the Umbanda house. The task was at that point to gather information about material culture in Umbanda for the ethnographic museum (Helinä Rautavaara museum) I was then working at.

15 However, I found out that there is more than one view about this process, and some Umbanda practitioners claim that the level of consciousness during incorporation is more related to the specific kind of mediunity each medium has, rather than the level of spiritual development.

16 Axé is a general term in Afro-Brazilian religions. It is the vital force of nature that is within all things and beings. A person can be considered to have a high or a low level of axé, as can any material object. For example, one of my interlocutors explained that the guia necklaces that are made of plastic threads (and plastic pearls) have almost no axé at all compared to those made of wool threads.

17 Afro-Brazilian religion originating from the state of Maranhão.

\section{REFERENCES}

Barad, Karen. 2007. Meeting the Universe Halfway. Quantum Physics and the Entanglement of Matter and Meaning. Durham: Duke University Press.

Bastide, Roger. 2001 [1958]. O candomblé da Bahia: rito nagô. São Paulo: Companhia das Letras.

Blanes, Ruy and Diana Espírito Santo. 2014. Introduction. - The Social Life if Spirits, edited by Ruy Blanes and Diana Espírito Santo. Chicago, IL; London: The University of Chicago Press, 1-32.

Brown, Diana. 1986. Umbanda. Religion and Politics in Urban Brazil. Ann Arbor, MI: UMI Research Press.

Cardoso, Vânia Zikàn. 2014. Spirits and Stories in the Crossroads. - The Social Life if Spirits, edited by Ruy Blanes and Diana Espírito Santo. Chicago, IL; London: The University of Chicago Press, 93-107.

Capone, Stephania. 2004. A busca da África no candomblé: tradição e poder. Rio de Janeiro: Pallas.

Da Silva, Vagner Gonçalves, ed. 2007. Intolerançia religiosa: impactos do Neopentecostalismo no campo religioso Afro-Brasileiro. São Paulo: Edusp.

Engler, Steven. 2012. Umbanda and Africa. - Nova Religio: The Journal of Alternative Emergent Religions 15 (4): 13-35.

Espírito Santo, Diana and Nico Tassi. 2013. Introduction. - Making Spirits: Materiality and Transcendence in Contemporary Religions, edited by Diana Espírito Santo and Nico Tassi. New York, NY; London: I.B. Tauris, 1-32.

Ferreira da Silva, Denise. 2005. Out of Africa? Umbanda and the "Ordering" of the Modern Brazilian Space. - Fragments of Bone: Neo-African Religions in the New World, edited by Patrick Bellegarde-Smith. Urbana, IL; Chicago, IL: University of Illinois Press, 32-51.

Fry, Peter and Edward MacRae. 1977. Mediunidade e sexualidade. - Religião \& Sociedade 1: 25-39.

Goldman, Marcio. 1984. A possessão e a construção ritual da pessoa no candomblé. A Master Dissertation. Universidade Federal do Rio de Janeiro, Museu Nacional.

Goldman, Marcio. 2011. An Afro-Brazilian Theory of a Creative process: An essay in Anthropological Symmetrization. - The Challenge of Epistemology: Anthropological Perspetives, edited by Cristina Toren and João de Pina Cabral. New York, NY: Berghahn books, 108-129. 
Hale, Lindsay. 2009. Hearing the Mermaid's Song: The Umbanda Religion in Rio de Janeiro. Albuquerque, NM: University of New Mexico Press.

Halloy, Arnaud. 2013. Objects, Bodies and Gods: A Cognitive Ethnography of an Ontological Dynamic in the Xangô Cult. - Making Spirits: Materiality and Transcendence in Contemporary Religions, edited by Diana Espírito Santo and Nico Tassi. New York, NY; London: I. B. Tauris, 133-158.

Haraway, Donna. 2003. The Companion Species Manifesto: Dogs, People and Significant Otherness. Chicago, IL: Prickly Paradigm Press.

Hayes, Kelly. 2011. Holy Harlots: Femininity, Sexuality \& Black Magic in Brazil. Berkeley, CA: University of California Press.

Henare, Amiria, Martin Holbraad and Sari Wastell. 2007. An Introduction. - Thinking Through Things: Theorizing Artefacts Ethnographically, edited by Amiria Henare, Martin Holbraad and Sari Wastell. New York, NY: Routledge, 1-31.

Holbraad, Martin. 2011. Can Things Speak? - Open Anthropology Cooperative Press. http://openanthcoop.net/press/2011/01/12/can-the-thing-speak/ (accessed May 22, 2016).

Holbraad, Martin 2012a. Truth in Motion: The Recursive Anthropology of Cuban Divination. Chicago, IL; London: University of Chicago Press.

Holbraad, Martin. 2012b. Things as Concepts: Anthropology and Pragmatology. - Savage Objects, edited by Godofredo Pereira. Lissabon: Guimarães, 17-30.

IBGE 2010 = IBGE: Instituto Brasileiro de Geografia e Estatistica. www.Ibge.gov.br/home/ (accessed May 22, 2016).

Jensen, Tina Gudrun. 1998. Umbanda and Its Clientele. - New Trends and Development in African Religion, edited by Peter B. Clarke. Westport, CT; London: Greenwood Press, 75-86.

Keane, Webb. 2009. The Evidence of the Senses and Materiality of Religion. - Objects of Evidence, edited by Matthew Engelke. Malden, MA: Wiley-Blackwell, 105-121.

Knappett, Carl and Labros Malafouris. 2008. Introduction. - Material Agency: Towards a NonAnthropocentric Approach, edited by Carl Knappett and Labros Malafouris. New York, NY: Spinger, 57-77.

Law, John. 1999. After ANT: complexity, naming and topology. - The Sociological Review 47: 1-14.

Law, John and Annemarie Mol. 2008. The Actor-Enacted: Cumbrian Sheep. - Material Agency: Towards a Non-Anthropocentric Approach, edited by Carl Knappett and Labros Malafouris. New York, NY: Spinger, 57-78.

Montero, Paula. 2001. Trânsito Religioso no Brasil. - São Paulo em Perspectiva 15 (3): 92-101.

Negrão, Lísias Nogueira. 1993. Umbanda: Entre a Cruz e a Encruzilhada. - Tempo Social; Rev. Sociol. 5 (1-2): 113-122.

Prandi, Reginaldo. 2005. Segredos guardados: orixás na alma brasileira. São Paulo: Compania das letras.

Sansi, Roger. 2013. We Worship Nature: The Given and the Made in Brazilian Candomblé. Making Spirits: Materiality and Transcendence in Contemporary Religions, edited by Diana Esírito Santo and Nico Tassi. New York, NY; London: I. B. Tauris, 81-104.

Spivak, Guarthry Chacravorty. 1988. 'Can the Subaltern Speak?' - Marxism and the Interpretation of Culture, edited by Cary Nelson and Lawrence Grossberg. London: Macmillan, 271-316.

Teixeira, Faustino. 2013. Os Dados Sobre Religiões no Brasil em Debate. - Debates do NER. Porto Alegre 14 (24): 77-84. 